\title{
UJI VIABILITAS VIRUS DENGUE SEROTIPE 3 PADA BEBERAPA GALUR SEL (CELL-LINE)
}

\author{
Dadan Supardan1, Jaka Widada², Tri Wibawa3 ${ }^{3}$, \\ dan Nastiti Wijayanti ${ }^{4}$ \\ 1 Jurusan Tadris IPA Biologi FITK IAIN Mataram \\ 2Jurusan Mikrobiologi Fakultas Pertanian Universitas Gadjah Mada \\ ${ }^{3}$ Fakultas Kedokteran Universitas Gadjah Mada \\ ${ }^{4}$ Jurusan Biologi Fakultas Biologi Universitas Gadjah Mada
}

\begin{abstract}
Abstrak
Infeksi virus dengue (DENV) merupakan infeksi yang menjadi salah satu masalah kesehatan utama di dunia dan salah satu infeksi yang sangat berbahaya terutama dinegara tropis seperti Indonesia.Infeksi dengue disebabkan oleh 4 serotipe virus dengue (DENV-1, DENV-2, DENV-3, dan DENV-4). Virus dengue serotipe 3 (DENV-3) merupakan serotipe dengan karakteristik lebih virulen. Sampai saat ini belum tersedia vaksin dan obat untuk pencegahan dan pengobatan infeksi virus dengue, sehingga penelitian penemuan obat demam berdarah sangat penting dilakukan, akan tetapi pengujian virus dengue pada kultur sel atau cell-line masih banyak mengalami kendala. Salah satu kendala yang sering dijumpai peneliti dalam pengujian senyawa tertentu terhadap virus dengue yaitu virus tersebut tidak mampu berkembang secara optimal pada beberapa jenis kulturcell-line, sehingga dilakukan pengujian untuk mengetahui viabilitas virus dengue pada beberapa kultur cell-line. Penelitian ini bertujuan untuk mengetahui kulturcell line yang paling cocok digunakan untuk berbagai pengujian infeksi DENV-3.
\end{abstract}

Kata kunci: Virus dengue serotipe 3, viabilitas, plaque assay 


\section{PENDAHULUAN}

Demam berdarah dengue merupakan penyakit yang penyebarannya paling cepat diantara penyakit dengan vektor nyamuk lainnya.Infeksi virus dengue (DENV) merupakan infeksi yang menjadi salah satu masalah kesehatan utama di dunia (Mackenzie et al., 2004) dan salah satu infeksi yang sangat berbahaya terutama di negara tropis seperti Indonesia.Infeksi dengue disebabkan oleh 4 serotipe virus dengue (DENV-1, DENV2, DENV-3, dan DENV-4) (Gubler, 1997).Virus dengue serotipe 3 merupakan serotipe yang lebih virulen yang berhubungan dengan tingkat keparahan penyakit yang menyebabkan gejala klinis yang berat (Mansyoer, 1999; Malvage, 2004; Soegijanto, 2006).Sampai saat ini belum tersedia vaksin dan obat untuk pencegahan dan pengobatan infeksi virus dengue, sehingga penelitian pembuatan vaksin dan penemuan obat demam berdarah masih terus dilakukan.

Mekanisme pasti dari patogenesis infeksi dengue masih sedikit diketahui karena belum adanya hewan model uji yang sesuai. Namun, faktor respon imun inang dan karakteristik virus dicurigai berkaitan dengan patogenesis infeksi dengue (Gubler, 1998). Virulensi virus dapat diketahui dari kecepatan replikasi, efek infeksi virus terhadap sel (sitopatologi), dan jumlah genom virus (Rico-Hesse, 2009). Kecepatan replikasi virus dengue secara in vitro dapat diketahui menggunakan beberapa uji, salah satunya dengan metode plaque assay dan Reverse TranscriptasePolymerase Chain Reaction (RT-PCR).

Secara in vitro, virus dengue mampu bereplikasi pada beberapa galur sel baik vertebrata maupun invertebrata.Replikasi virus dengue sangat bergantung pada jenis sel inang dan juga tahap diferensiasi sel. Galur sel nyamuk, C6/36 diketahui merupakan galur sel yang paling sensitif untuk isolasi virus dengue (Igarashi, 1978).Sementara itu, beberapa jenis galur sel mamalia yang dapat mendukung pertumbuhan virus dengue diantaranya sel monosit, fibroblas, sumsum tulang belakang, epitelial, dan endotelial (Rothman, 1997).Namun, belum diketahui galur sel mamalia terbaik untuk mendukung petumbuhan virus 
dengue dan menghasilkan titer virus yang tinggi.Sedikitnya informasi mengenai karakter pertumbuhan virus dengue pada galur sel mamalia merupakan salah satu faktor pembatas dilakukannya analisis patogenesis dan uji pembuatan vaksin dan obat terhadap virus dengue secara in vitro.Oleh karena itu, penelitian ini dilakukan untuk mengetahui galur sel mamalia alternatif terbaik bagi pertumbuhan virus dengue dengan melihat karakter pertumbuhan virus dengue.Parameter pertumbuhan virus dengue pada tiap sel diketahui dengan membandingkan kecepatan replikasi dan jumlah titer virus dengue pada setiap galur sel. Tujuan dari penelitian yaitu untuk mengetahui karakter pertumbuhan virus dengue pada enam galur sel dan menentukan galur sel mamalia alternatif terbaik untuk pertumbuhan virus dengue.

\section{METODE PENELITIAN}

Penelitian ini menggunakan jenis penelitian eksperimen dengan pendekatan kuantitatif. Pelaksanaan penelitian dilakukan pada bulan Mei 2013 di Laboratorium Parasitologi Fakultas Kedokteran Universitas Gadjah Mada, Yogyakarta. Penelitian ini menggunakan sampel virus dengue serotype 3 dan 3 jenis cell-line (C6/36 cell line, BHK, dan Vero) serta menggunakan metode kulturcell-line secara in-vitro dan metode plaque assay. Sampel virus dengue dan BHK cell line didapatkan dari Lembaga Penelitian Eijkman Jakarta, sampel C6/36 cell-line dari Laboratorium Parasitologi UGM, dan Vero cell-line dari pusat penelitian kanker UGM (CCRC UGM).

Cell line BHK-21, C6/36 dan Vero pada fase pertumbuhan eksponensial (90-95\% konfluen) dipanen dan ditumbuhkan pada 24-wellplatesdengan jumlah sel 1,5 x $10^{5}$ sel setiap well kemudian diinkubasi 24 jam (atau sampai 90-95 \% konfluen). Stok virus diencerkan dengan medium DMEM yang mengandung 2\% FBS (sel BHK-21 dan Vero, sel C6/36 menggunakan medium MEM) dari $10^{-1}$ sampai $10^{-6}$ dengan cara ditambahkan sebanyak $50 \mu \mathrm{l}$ supernatant virus (stok) ke dalam $450 \mu \mathrm{l}$ medium, kemudian diambil $50 \mu$ d dari pengenceran $10^{-1}$ dan ditambahkan pada tube

120 BIOTA: Jurnal Tadris IPA Biologi FITK IAIN Mataram 
selanjutnya sehingga didapatkan pengenceran $10^{-2}$ dan seterusnya. Dua ratus mikrolitersetiap pengenceran virus ditambahkan pada setiap wellyang mengandung jenis sel dan dibuat rangkap tiga, kemudian diinkubasi pada suhu $37^{\circ} \mathrm{C}$ dalam $\mathrm{CO}_{2}$ 5\% selama 1 jam (setiap 15-20 menit digojok), khusus untuk sel $\mathrm{C} 6 / 36$ diinkubasi pada suhu $28{ }^{\circ} \mathrm{C}$ tanpa $\mathrm{CO}_{2}$. Selanjutnya, supernatan dari setiap well dibuang, kemudian segera ditambahkan $500 \mu \mathrm{l} 1 \%$ karboksimetilselulosa yang mengandung $2 \%$ FBS, fungizone $0,5 \%$ dan $1,5 \%$ penstrep, inkubasi pada suhu $37{ }^{\circ} \mathrm{C}$ dalam $\mathrm{CO}_{2} 5 \%$ selama 3 hari. Setelah inkubasi, fiksasi sel dengan menggunakan $3,7 \%$ formalin selama 35 menit, buang overlay metilselulosa dan cuci dengan air mengalir, kemudian sel di warnai dengan $200 \mu \mathrm{l}$ 1\% kristal violet selama 5 menit. Setelah distaining selama 5 menit, buang kristal violet dan cuci dengan air mengalir kemudian inkubasi pada suhu $55^{\circ} \mathrm{C}$ atau suhu ruang agar plaque terlihat lebih jelas, kemudian dihitung plaque forming unit/ml untuk menentukan titer virus menggunakan rumus yang digunakan Lambeth et al. (2005), sebagai berikut:

\section{HASIL DAN PEMBAHASAN}

\section{Analisis Kultur Sel dan Propagasi Virus Dengue Serotype 3}

Sel yang digunakan dalam penelitian adalah BHK-21, C6/36, dan Vero. Hasil pengamatan tiga galur sel kultur setelah masa inkubasi 72 jam secara mikroskopis menggunakan mikroskop inverted diperlihatkan pada Gambar 1. Pada gambar terlihat ketiga sel memiliki tipe pertumbuhan yang sama, yaitu tumbuh dengan menempel pada substrat (adherent-dependent) sehingga membentuk monolayer. 


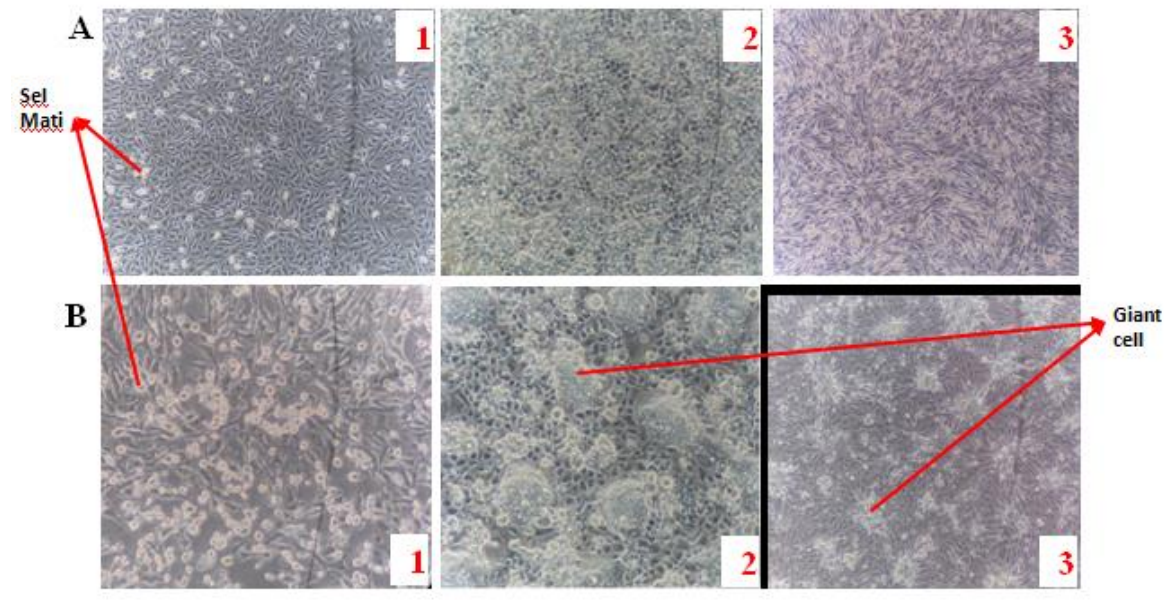

\section{Gambar 1}

Morfologi ketiga galur sel, pengamatan dibawah mikroskop inverted perbesaran 200x. A) Galur sel (cell line) kontrol, B) Galur sel uji. A.1, 2, 3) kontrol sel BHK-21, C6/36 dan Vero. B.1, 2, 3) Galur sel uji BHK-21, C6/36 dan Vero

Berdasarkan hasil pengamatan menggunakan mikroskop inverted dengan perbesaran 200x terlihat perbedaan morfologi kultur sel kontrol (sel tanpa infeksi virus) dengan kultur sel uji (sel yang telah diinfeksi virus). Morfologi pada sel kontrol terlihat tumbuh normal dan sehat, hal ini ditandai dengan ukuran sel yang seragam dan hanya sebagian kecil sel yang mati, berbeda dengan morfologi yang ditunjukan pada sel uji, ketiga sel tersebut menunjukan pertumbuhan yang tidak normal.Pada sel uji BHK-21 morfologi selnya terlihat lebih panjang dan lebih besar serta banyak sel bulat yang berwarna lebih putih dan mengambang yang menandakan sel tersebut telah mati, selain itu terlihat ruang kosong pada permukaan flask yang diakibatkan oleh sel terlepas.Sel yang lisis dan terlepas dari permukaan flask diperkirakan akibat infeksi virus dengue serotipe 3. Morfologi galur sel C6/36 dan Vero juga terlihat berbeda antara sel kontrol dan sel uji, pada sel uji menunjukan adanya perubahan morfologi yaitu sel mengumpul dan membentuk sel yang sangat besar (Giant cell) yang menandakan sel tersebut terinfeksi virus. Beberapa tanda pada sel uji yang ditunjukan pada Gambar 1B merupakan 
efek sitopatik yaitu efek yang ditimbulakan oleh adanya infeksi suatu virus pada sel hidup. Hasil tersebut juga sesuai dengan beberapa penelitian sebelumnya, salah satunya disebutkan pada penelitian Guzman and Kouri (1996), bahwa tanda-tanda terjadinya efek sitopatik yaitu terbentuk giant cell, permukaan sel tidak rata (bergerigi) dan banyak sel lisis. Berdasarkan hasil tersebut ketiga galur sel mampu atau viabel untuk diinfeksi virus dengue serotipe 3, akan tetapi efek sitopatik paling jelas terlihat pada galur sel C6/36. Hal tersebut diduga disebabkan karena sel C6/36 merupakan sel saliva nyamuk yang merupakan vektor alami virus dengue, sehingga tingkat sensitifitasnya lebih tinggi dibandingkan galur sel yang lain.

\section{Metode Plaque Assay (penghitungan titer virus) pada Kultur Cell-Line BHK-21, C6/36 dan Vero}

Ada beberapa metode yang populer digunakan dalam menentukan titer virus, akan tetapi gold standard menurut WHO (2007) dalam menentukan titer virus yaitu menggunakan metode Plaque Assay. Lambeth et al. (2005), juga menyebutkan bahwa metode plaque assay lebih sensitif dan dapat digunakan untuk menentukan jumlah titer virus yang relatif rendah atau sedikit.

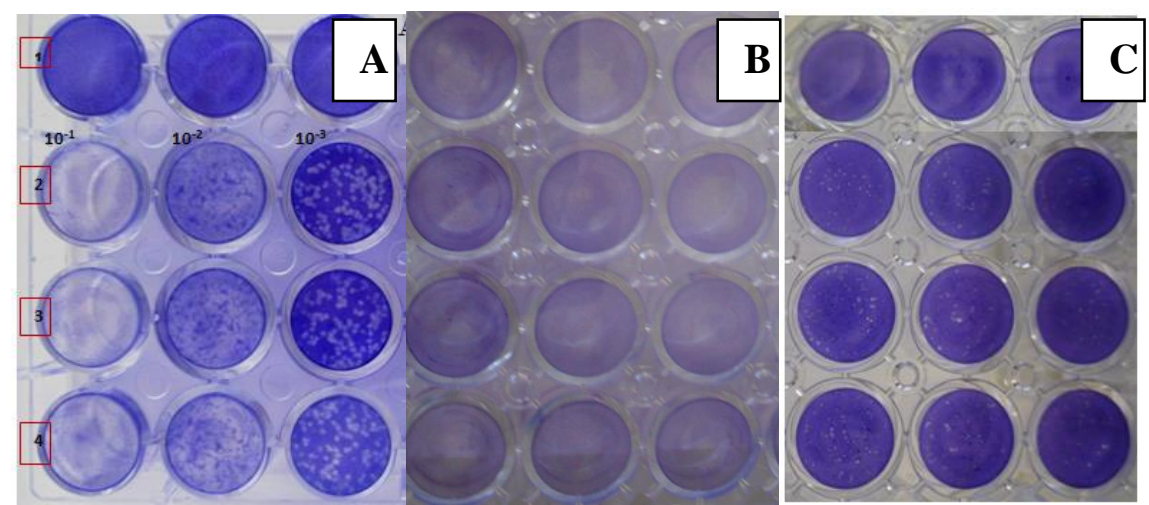

Gambar 2. Hasil uji plaque virus dengue serotipe 3 dengan menggunakan tiga galur sel. A) Sel BHK-21, B) Sel C6/36, C) sel Vero. Baris ke-1 merupakan kontrol sel (galur sel yang tidak diinfeksi virus), baris ke-2, 3, dan 4 adalah uji plaque dengan menggunakan 3 pengenceran yaitu $10^{-1}$ sampai $10^{-3}$. 
Berdasarkan hasil uji pada sel BHK-21 (Gambar 2A) dan hasil perhitungan menggunakan rumus, plaque yang terbentuk pada pengenceran $10^{-3}$ yaitu 92 plaque sehingga didapatkan titer virus 4,6 x $10^{5} \mathrm{PFU} / \mathrm{ml}$ dengan lama inkubasi selama 3 hari setelah infeksi, akan tetapi titer virus pada pengenceran $10^{-1}$ dan $10^{-2}$ tidak dapat dihitung dikarenakan plaque yang dihasilkan lebih banyak sehingga plaque tersebut menyatu antara satu dengan yang lainnya. Hal tersebut dikarenakan titer virus pada pengenceran $10^{-1}$ dan $10^{-2}$ lebih tinggi, sehingga sel yang lisis lebih banyak. Berbeda dengan jumlah plaque yang dihasilkan pada sel Vero (Gambar 2C), pengenceran $10^{-1}$ menghasilkan jumlah ratarata plaque dari 3 ulangan yaitu 57 plaque dengan hasil perhitungan titer 2,85 x $10^{3} \mathrm{PFU} / \mathrm{ml}$. Pada pengenceran $10^{-3}$ terbentuk 31 plaque sehingga dihasilkan 1,55 x $10^{5} \mathrm{PFU} / \mathrm{ml}$, jumlah ini berbeda dengan hasil uji pada sel BHK-21. Selain itu, plaque yang terbentuk pada sel BHK-21 lebih jelas dibandingkan dengan plaque yang terbentuk pada sel Vero, hal ini bisa disebabkan oleh banyak faktor, salah satunya adalah tingkat sensitifitas setiap sel terhadap virus yang berbeda-beda.

Pada galur sel ke-3 yaitu sel C6/36 (Gambar 2B) tidak ada plaque yang dihasilkan baik pada pengenceran $10^{-1}, 10^{-2}$ dan $10^{-3}$, hal ini dapat disebabkan oleh banyak hal, selain sensitivitas sel, lama inkubasi setelah infeksi virus juga dapat mempengaruhi jumlah plaque yang terbentuk, begitu juga dengan titer virus yang dihasilkan.Henchal \& Putnak (1990), menyebutkan bahwa titer tertinggi yang dapat dicapai dari hasil propagasi virus dengue sekitar $10^{8}-10^{9} \mathrm{PFU} / \mathrm{ml}$. Titer virus (PFU/ml) dihitung berdasarkan plaque yang terbentuk pada setiap faktor pengenceran.Berdasarkan hasil uji plaque pada ketiga galur sel, didapatkan hasil plaque terbaik dan terbanyak pada galur sel BHK-21 dengan lama inkubasi 3 hari setelah infeksi.Hal ini diduga disebabkan oleh perbedaan karakteristik dari ketiga sel yang digunakan.Pada penelitian Guskey \& Jenkin (1975), menyebutkan bahwa karakteristik lipid yang terkandung dalam sel BHK-21 telah diketahui dan terbukti dapat diinfeksi banyak kelompok virus, termasuk kelompok arbovirus.Sel BHK-21 juga sering digunakan untuk memproduksi vaksin (Beynon \& Howe 2004). 
Uji Viabilitas Virus Dengue Serotipe 3...

\section{PENUTUP}

\section{Kesimpulan}

Berdasarkan hasil penelitian dapat disimpulkan bahwa ketiga galur sel (cell line) viabel untuk diinfeksi virus dengue serotype 3, akan tetapi hasil terbaik dengan metode plaque assay yaitu pada galur sel BHK-21.

\section{Saran}

Saran yang dapat peneliti berikan yaitu: 1) Perlu dilakukan uji molekuler secara genetik untuk memastikan cara penginfeksian virus dengue terhadap galur sel yang berbeda, 2) Perlu dilakukan uji infeksi menggunakan galur sel mamalia yang lebih banyak, 3) Sebaiknya digunakan galur sel BHK-21 untuk uji lanjutan dengan menggunakan metode plaque assay dan virus dengue serotype 3 .

\section{DAFTAR PUSTAKA}

Alen, M. M. F., and Schols D., 2012.Dengue Virus Entry as Target for Antiviral Therapy.J Trop Med. 628:1-13

Ara, I., Bukhari, N. A., Aref, N. M., Shinwari, M. M. A., and Bakir, M. A., 2012. Antiviral Activities of Streptomycetes Against Tobacco Mosaic Virus (TMV) in Datura plant: Evaluation of different organic compounds in their metabolites. Afr I Biotechnol. 8:2130-2138.

Berdy J., 2005. Bioactive Microbial Metabolites (review article). J. Antibiot. 58(1):1-26

Beynon, R. \& C. Howe. 2004. Animal cell culture and technology. Garland science/BIOS Scientific Publishers. New York: $\mathrm{x}^{+}$ $288 \mathrm{hlm}$.

Gubler, D.J. 1998. Dengue and dengue hemorrhagic fever. Clinical Microbiology Reviews 11 (3): 480--498.

Guskey, L.E, \& H. M. Jenkin. 1975. Adaptation of BHK-21 cells to growth in shaker culture and subsequent challenge by 
Japanese Encephalis Virus. American Society for Microbiology.

Guzman MG, Kouri G., 1996. Advances in dengue diagnosis. Clin Diagn Lab Immunol.3:621-7.

Hidari, K. I. P. J., Takahashi, M., Arihara, M., Nagaoka, K., Morita, and Suzuki T., 2008. "Structure and anti-dengue virus activity of sulfated polysaccharide from a marine alga," Biochem and Biophysical Research Comm., 376:91-95.

Henchal, E. A., and Putnak J. R., 1990.Dengue virus. Clin Microbiol Reviews. 3(4): 376--389.

Igarashi, A. 1978.Isolation of a singh's Aedes albopictus cell clone sensitive to dengue and chikungunya viruses. Journal of General Virology 40: 531--544.

Julander, J. G., Perry, S. T., and Shresta, S., 2011. Important advance in the field of anti-dengue virus research. Antiviral Chem.And Chemotherapy. 21:105-116

Jiang, L., Wu, X., Wu, Y., Bai, Z., Jing, Q., Luo, L., Dong, Z., Yang, Z., Xu, Y., Cao, Y., Di B., Wang., and Wang, M., 2013. Molecular epidemiological and virological study of dengue virus infections in Guangzhou, China, during 2001-2010. Virol J. 10(4):1-9

Jensen, P. R., Williams, P. G., Oh, D. C., Zeigler, L., and Fenical, W., 2007.Species-specific secondary metabolite production in marine actinomycetes of the genus Salinispora. Appl Microbiol Biotechnol. 4:1146-52.

Kannabiran, S., 2009. Cytotoxic and antimicrobial potential of actinomycete species Saccharopolyspora salina VITSDK4 isolated from the Bay of Bengal Coast of India. Am J Inf Dis. 5(2):90-98.

Lambeth, C. R., White, L. J., Johnston, R. E., and Silva, A. M. D., 2005. Flow Cytometry-Based Assay for Titrating Dengue Virus. $J$ Clin Microbiol. 7:3267-3272.

Lee, J-G., Ick D. Y., and Won G., 2007. Differential Antiviral Activity of Benzastatin C and Its Dechlorinated Derivative from Streptomyces nitrosporeus.Biol. Pharm. Bull. 4:795-797

Mackenzie J. S., Gubler D. J., and Petersen L. R., 2004. Emerging flaviviruses: the spread and resurgence of Japanese 
encephalitis, West Nile and dengue viruses. Nature Med.10:98-109.

Malvage G. N., Fernando S., D. J., and Sonevirate, S. L., 2004.Dengue Viral Infection.Post grad med J. 80:588-601

Mansyoer A., 1999. Kapita Selekta kedokteran. Edisi Kedua, Penerbit Media Aesculapius. FK UI Jakarta: 428 - 430.

Mohamed, H. S. and Galal, A. M., 2005. Identification and Antiviral Activities of Some Halotolerant Streptomycetes Isolated from Qaroon Lake. Int J Agri Biol. 5:747-753.

Omura, S., Ikeda, H., Ishikawa, J., Hanamoto, A., Takahashi, C., Shinose, M., Takahashi, Y., Horikawa, H., Nakazawa, H., Osonoe, T., Kikuchi, H., Shibai, T., Sakaki, Y., and Hattori, M., 2001. Genome sequence of an industrial microorganism Streptomyces avermitilis: deducing the ability of producing secondary metabolites. Proc Natl Acad Sci. 98:12215-20.

Oskay, M., Tamer, A., Usame., and Azeri, C., 2004. Antibacterial activity of some actnomycetes isolated from farming soils of Turkey. Afr J Biotechnol. 9:441-446.

Procopio, R. E. D. L., Silva, I. R. D., Martins, M. K., Azevedo J. L. D., and Araujo, J. M. D., 2012. Antibiotics produced by Streptomyces. Braz J Infect Dis. 16(5):466-471.

Ohnishi, Y., Ishikawa, J., Hara, H., Suzuki, H., Ikenoya, M., Ikeda, H., Yamashita, A., Hattori, M., and Horinouchi, S., 2008.Genome sequence of the streptomycin-producing microorganism Streptomyces griseus IF0 13350.J Bacteriol. 190:4050-60.

Ravikumar, S., Fredimoses, M., and Gnanadesigan, M., 2012.Anticancer property of sediment actinomycetes against MCF-7 and MDA-MB-231 cell lines. Asian Pac J Trop Biomed. 2(2): 92-96

Rico-Hesse, R. 2009.Dengue virus markers of virulence and pathogenicity. Future Virology 4(6): 1--13.

Rothman, A.L. 1997. Viral pathogenesis of dengue infections. Dalam: Gubler, D.J. \& G. Kuno (eds.). 1997. Dengue and dengue hemorrhagic fever. $\mathrm{CAB}$ International, New York: 245--271.

Sadek, P. C., 2002. The HPLC Solvent Guide Second Edition. John Wiley and Sons, Inc.New York. 